\title{
Poor Relief, Informal Assistance, and Short Time during the Lancashire Cotton Famine $^{1}$
}

\author{
George Boyer \\ Department of Labor Economics, School of Industrial and Labor Relations, Cornell \\ University
}

This paper presents new evidence concerning the importance of poor relief as a source of income assistance for unemployed operatives during the Lancashire cotton famine. My comparison of weekly data on the number of relief recipients in 23 distressed poor law unions with estimates of weekly cotton consumption for the period November 1861 to December 1862 suggests that the average length of time between becoming unemployed and receiving poor relief was less than 2 months. This result is shown to be consistent with available evidence on working class saving. Given the meager amount of informal assistance available to them, most operatives were forced to turn to the poor law for income assistance within 4 to 8 weeks of becoming unemployed.

In a recent paper in this journal, Kiesling (1996) correctly argues that the relationship between cyclical unemployment and poor relief in Victorian Lancashire was not as straightforward as implied by my analysis of the economics of poor relief in industrial cities (Boyer, 1990, Chap. 8). I sought to explain how cost-minimizing employers responded to cyclical fluctuations in demand and did not examine the extent to which workers who had lost their jobs or had been put on short time used "informal assistance" or private charity to relieve their distress. In so doing, I did not mean to suggest that such alternatives did not exist.

I agree with Kiesling that informal sources of assistance, such as individual saving, intrafamily transfers, and credit, played a significant role during downturns. We disagree, however, on the relative importance of poor relief and informal assistance. Kiesling (1996, pp. 67,81) maintains that unemployed textile workers "generally relied on informal sources of income assistance" and that "the poor law provided an insurance institution of final recourse," while I contend that, before the beginning of the Crusade against Outrelief in the late 1860s, poor relief was a major source of income assistance to unemployed workers and that informal sources were relatively less important for all but the highest-paid cotton operatives.

In this paper I reexamine the roles played by poor relief, informal assistance, private charity, and short time during the Lancashire cotton famine. Section I presents new evidence concerning the length of the lag between declines in cotton production and increases in the number of poor relief recipients. I construct weekly series for raw cotton consumption and for the number of relief recipients in 23 Lancashire/Cheshire poor law unions. A comparison of the trends of these series suggests that the lag between becoming unemployed and receiving poor relief was relatively short and therefore that the importance of the poor law as a source of income assistance was greater, and the role of informal assistance smaller, than Kiesling maintains. Section II examines the role of individual saving and other informal sources of assistance and offers a rough estimate of the length of time that, on average, an unemployed cotton operative and his family could subsist on informal assistance. Section III examines the administration of poor relief and private charity in Lancashire cities during the cotton famine and earlier downturns, while Section IV examines the role of short time. My conclusions are summarized in Section V.

\footnotetext{
1 I thank Stanley Engerman, Andrew Rutten, and two anonymous referees for helpful comments, and Jesse Leary for able research assistance.
} 


\section{Section I.}

Kiesling contends that cotton operatives were very reluctant to apply for poor relief, which led them when unemployed "to take advantage of all other means [of income assistance] to the extent possible, for as long as they lasted.... As workers and their families dissipated their savings and assets, they had little alternative but to apply for public relief or to request charitable assistance" (Kiesling, 1996, pp. 71-72). She offers an indirect test of the hypothesis that unemployed workers depleted their informal sources of income before requesting poor relief. The test consists of measuring the length of the lag between the beginning of the cotton famine and the sharp increase in the number of able-bodied and non-able-bodied persons receiving poor relief in six Lancashire poor law unions ${ }^{2}$. The longer the lag, the more important the use of informal sources of income. Unfortunately, data on the number of able-bodied and non-able-bodied relief recipients are available for only 2 weeks a year (the first week in January and the first week in July). Kiesling (1996, pp. 78-79) concludes from the sharp increase in the number of relief recipients between July 1862 and January 1863 that the lag between the beginning of the famine and the widespread application for poor relief was as long as 14 months (October 1861 to January 1863) and therefore that the poor law was "an institution of last resort." Finally, Kiesling contends that, since a large share of the non-able-bodied were "infirm relatives of able-bodied cotton workers," the fact that the numbers of both able-bodied and non-able-bodied relief recipients peaked in January 1863 indicates that "families would pool resources until they were exhausted, and then request public relief at the same time, if at all" (1996, p. 77).

The view that cotton workers were strong believers in self-help and were averse to applying for poor relief even when unemployed is shared by many historians, although some argue that workers were much more averse to being relieved in workhouses than to receiving outdoor relief ${ }^{3}$. Despite their distaste for the poor law, most factory workers were forced to apply for relief within a short time of becoming unemployed. According to MacKinnon (1986), a worker's application for relief indicated that his assets were exhausted and that he was a poor credit risk. Pauperism was undesirable "as long as relatively few people received relief.... Therefore, there will be some lag between the onset of unemployment and recourse to the poor law. Given the low level of assets, this was likely to be fairly short, and there is no evidence that the gap changed with time" (MacKinnon, 1986, pp. 301-302).

Boot (1990) estimated the length of this lag for Manchester factory workers during the downturn of 1847/1848, by comparing changes in unemployment and in numbers receiving poor relief. He concluded that "the average lag between becoming unemployed and receiving relief" was about 6 weeks (1990, p. 225). Boot argued that informal assistance was "more acceptable" than poor relief for factory workers, and yet he was surprised that the lag was "as long as six weeks. . . given the low level of working-class savings in the 1840s" (1990, p. 225). It is difficult to reconcile Boot's findings with Kiesling's conclusion that the lag between the beginning of the cotton famine and the sharp increase in the number of able-bodied persons receiving poor relief was as long as 14 months ${ }^{4}$. Kiesling acknowledges Boot's result, but she offers no explanation why unemployed cotton operatives were able to subsist on informal assistance several months longer before applying for relief in 1862 than in 1847.

In fact, the lag between becoming unemployed and receiving relief cannot be measured at all precisely with the semiannual data on the number of able-bodied and non-able-bodied relief recipients used by Kiesling. However, weekly data on the total number of relief recipients are

\footnotetext{
2 The poor law unions used by Kiesling are Ashton-under-Lyne, Bolton, Oldham, Preston, Rochdale, and Wigan.

3 For example, Clapham (1932, p. 427) writes that in 1860 "wage-earners and their families, especially in the towns, had lost none of their horror of 'the house'; nor had there been any change in their willingness to accept outdoor relief in emergency."

4 Part of the difference is caused by the fact that Boot estimated the length of the "lag between becoming unemployed and receiving relief," while Kiesling estimated the lag between "the large increase in short time work" and the peak in numbers receiving relief.
} 
available for the period of the cotton famine. If, as Kiesling maintains, the trends in the ablebodied and non-able bodied series are similar, then the weekly series should be a reasonable proxy for the trend in the number of able-bodied relief recipients.

Figure 1 shows the number of persons receiving poor relief in 23 "distressed" unions and townships in Lancashire and Cheshire for each week from November 1861 through the first week of December 1862, when the number of paupers reached its highest point ${ }^{5}$. The increase in the number of relief recipients during the cotton famine took place in three phases. From the first week in November 1861 to the third week in February 1862, the number of relief recipients increased by $78 \%$, from 47,039 to 83,559 . The average increase per week was slightly more than 2400. From the third week in February to the last week in June 1862, the number of paupers increased by only 16,600, or 924 per week. The number of relief recipients began to increase sharply in late July. From the third week in July through the first week in October, the number of paupers increased by 5961 per week, while from the first week in October through the third week in November the number of relief recipients increased by 12,057 per week. Overall, from midJuly to early December the number of paupers increased by 161,738 . The feet that the number of persons receiving poor relief began to increase rapidly in July 1862 indicates that Kiesling's (1996, p. 78) conclusion that "the large increase ... [in the number of paupers] does not happen until January 1863" is misleading, a result of her use of semiannual data.

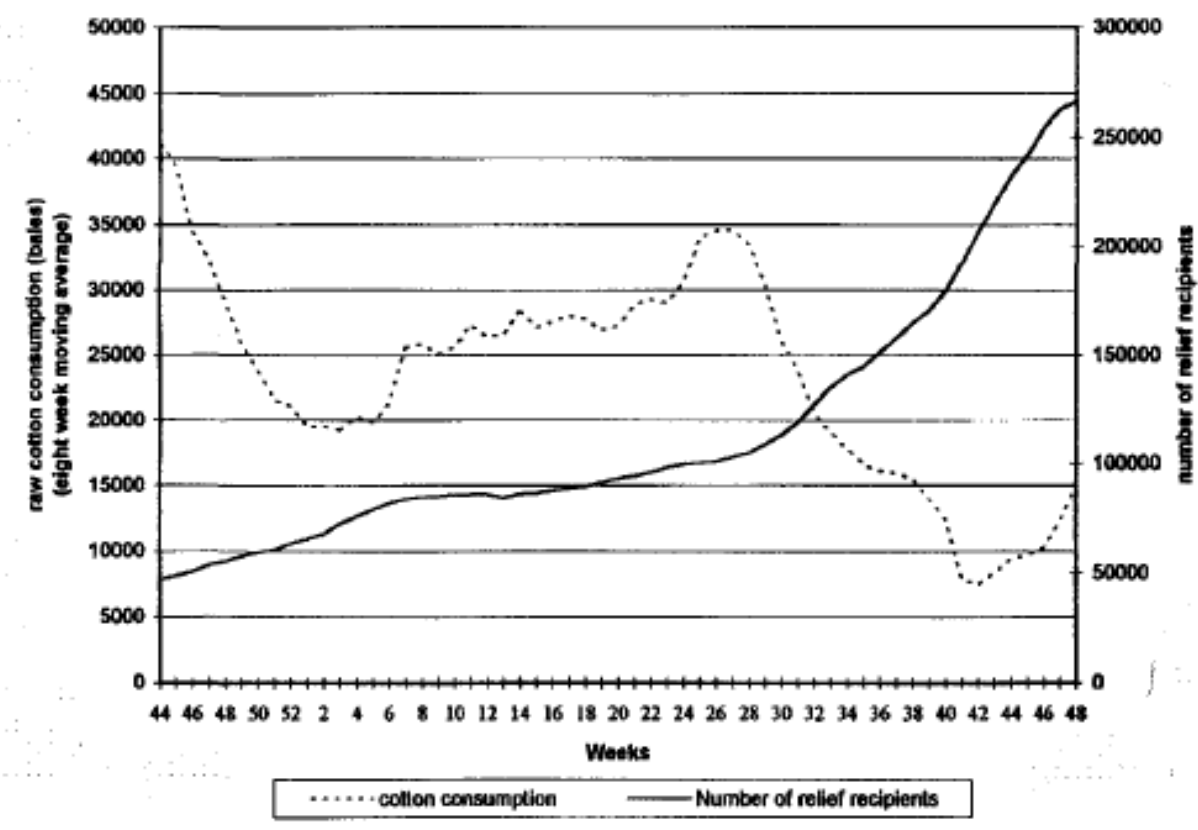

FIG. 1. Number of relief recipients and cotton consumption, November 1861-December 1862.

In order to determine the role played by poor relief during the cotton famine, we need to compare movements in numbers on relief with movements in unemployment or cotton production. No unemployment series exist, but The Economist reported weekly estimates of the year-to-date consumption of raw cotton, from which I constructed estimates of cotton consumption for each week from September 1861 to December 1862. The resulting series, presented in the Appendix, sometimes fluctuates sharply from week to week, but when averaged

5 Data on the number of relief recipients in 24 poor law unions and townships were obtained from Great Britain, Parliamentary Papers (1863, LII, pp. 182-192). I excluded Liverpool because it contained very few cotton workers and because the number of relief recipients there was determined largely by conditions at the port. For example, the sharp increase in relief recipients in February and March 1862 was "entirely due to ... the prevalence of easterly winds, which stopped the principal business of the port." 
over several weeks the data probably are a reasonable measure of the trend in cotton production during the famine ${ }^{6}$.

Figure 1 reports for each week from November 1861 to December 1862 the average consumption of raw cotton over the previous 8 weeks. Cotton consumption fell sharply during the last 2 months of 1861, from slightly more than 40,000 to about 20,000 bales per week. In February 1862 it rebounded to above 25,000 bales per week and then fluctuated between 25,000 and 30,000 bales until mid-June, when it briefly increased to nearly 35,000 bales per week. In early July cotton consumption began to decline very rapidly, felling below 20,000 bales per week in mid-August and below 10,000 bales per week in early October.

TABLE 1

Raw Cotton Consumption, January 1861-November 1862

\begin{tabular}{|c|c|c|}
\hline & $\begin{array}{c}\text { Average cotton } \\
\text { consumption bales/week }\end{array}$ & Index \\
\hline \multicolumn{3}{|l|}{1861} \\
\hline January 1-June 27 & 44,712 & 100.0 \\
\hline October 4-November 14 & 38,017 & 85.0 \\
\hline November 15-December 26 & 16,787 & 37.5 \\
\hline \multicolumn{3}{|l|}{1862} \\
\hline January 1-July 3 & 29,929 & 66.9 \\
\hline July 4 -August 28 & 17,808 & 39.8 \\
\hline August $29-$ October 16 & 6,857 & 15.3 \\
\hline October 17-November 28 & 14,172 & 31.7 \\
\hline
\end{tabular}

Source. The Economist, weekly issues, January 1861-December 1862.

Table 1 compares average weekly cotton consumption for various periods during the cotton famine with consumption during the first 6 months of 1861, before the famine began. Consumption began to decline in October 1861, then plummeted to 38\% of its prefamine level in the last 6 weeks of the year. It rebounded in the first half of 1862 to an average of nearly 30,000 bales per week, two-thirds of its prefamine level. However, cotton consumption fell sharply in the summer of 1862; from July 4 to August 28 average weekly consumption was only $60 \%$ of its level during the previous 6 months. In September consumption declined even further, to its lowest point during the famine. From August 29 to October 16 average weekly consumption was a mere 6857 bales, less than average daily consumption during the previous boom. Consumption increased slightly in late October and November, but remained less than a third of its prefamine level.

A comparison of the trends of cotton consumption and numbers on relief suggests that the lag between becoming unemployed and applying for poor relief was relatively short. The sharp fall in cotton consumption during the final 6 weeks of 1861 was followed by a rapid increase in the number of relief recipients in January and early February 1862. The rebound in cotton consumption in the first half of 1862 caused the rate of increase in relief recipients to slow to a trickle from March to June. The drop in cotton consumption in July and August led to a rapid increase in the number of relief recipients beginning in late July. Finally, the collapse in cotton

\footnotetext{
6 Kiesling (1996, p. 76) maintains that the trend in raw cotton consumption "generally approximates the trend of the distress in Lancashire."
} 
consumption from September through mid-October was followed by a sharp acceleration in the rate of increase in relief recipients beginning in early October. In sum, the three periods when cotton consumption dropped sharply (November-December 1861, July-August 1862, SeptemberOctober 1862) were followed by rapid increases in the number of relief recipients beginning roughly 6, 4, and 4 weeks later. In each case, the rapid increase in numbers on relief lasted about 7-8 weeks, with half of the total increase occurring within 4 weeks. Assuming that many firms initially responded to a decline in production by reducing hours rather than laying off workers, it seems reasonable to conclude that the average length of time between becoming unemployed and applying for relief was around 4-8 weeks. I will argue in Section II that such a lag is consistent with available evidence on subsistence levels and the extent of individual saving.

Kiesling's conclusion that the poor law was "an institution of last resort" is based on her finding that there was a lag of up to 14 months between the beginning of the cotton famine and the peak in the number of relief recipients. But her calculation tells us little about the role of poor relief, because the cotton famine got much worse over time. In the first half of 1862, weekly cotton consumption averaged $67 \%$ of its prefamine level; during the second half of 1862 it averaged only $25 \%$ of its prefamine level. The rapid increase in the number of relief recipients in the second half of 1862 was a result of the sharp decline in cotton consumption that occurred at the same time. It is not evidence that the poor law was an institution of last resort. In fact, the data presented here indicate that the lag between becoming unemployed and receiving poor relief was relatively short, which suggests that the poor law played an important role in the relief of unemployed operatives during the cotton famine.

The data on the number of relief recipients in Fig. 1 are for 23 "distressed" poor law unions and townships in Lancashire and Cheshire, while Kiesling focuses on only 6 of these unions: Ashton-under-Lyne, Bolton, Oldham, Preston, Rochdale, and Wigan. If the cotton famine affected individual poor law unions differently, then Kiesling's conclusions regarding the role of poor relief might be determined in part by her choice of unions. Table 2 shows the percentage of the population receiving poor relief at five points of time for the 13 largest distressed unions ${ }^{7}$. The rate of increase in the share of relief recipients during the early months of the cotton famine differed sharply across unions. From September 1861 to February 1862, the percentage of the population receiving poor relief more than tripled in Blackburn, Preston, and Stockport, increased by $160 \%$ in Ashton-under- Lyne, but rose by only $47 \%$ in Chorlton, by $37 \%$ in Bolton, and by $16 \%$ in Wigan. The increase in the number of paupers slowed significantly during the spring of 1862. Still, Table 2 shows that in Ashton numbers on relief were 5 times greater in June 1862 than in September 1861, 4 times greater in Blackburn and Stockport, and 3.75 times greater in Preston. In all unions except Wigan the number of paupers increased sharply during the summer and fall of 1862.

The large differences across unions in the rate of increase in numbers on poor relief during the early months of the famine were caused by differences "in their dependence on the cotton industry [and] on the supply of American cotton," and in the types of cotton cloth produced (Farnie, 1979, p. 158; Purdy, 1862, p. 377). In Ashton-under-Lyne, Blackburn, Preston, and Stockport, where numbers on relief increased sharply, the ratio of adults employed in the cotton industry to population was high, in 1861 ranging from 18\% in Preston to 22\% in Blackburn $^{8}$. On the other hand, in Wigan, where numbers on relief increased very slowly before the fall of 1862, employment in the cotton industry was relatively low. In

\footnotetext{
7 Data on the number of relief recipients from November 1861 to December 1862 are from Great Britain, Parliamentary Papers (1863, LII, pp. 182-192). Data for August 1861 to October 1861 are from Great Britain, Parliamentary Papers (1862, XLIX, Pt. 1, pp. 122177).

8 Data on the number of "persons aged 20 and upwards engaged in cotton manufacture in 1861" are from Great Britain, Parliamentary Papers (1863, LII, pp. 196-219). Data on the adult population of poor law unions are not available. The percentages reported in the text and in the first column of Table 2 were calculated as the number of adults employed in the cotton industry divided by the
} 
Bolton, another union in which numbers on relief increased slowly, "the local economy was superbly balanced and diversified.... As a centre of medium-fine spinning Bolton consumed far less cotton than Blackburn and did not depend so much upon American cotton" (Farnie, 1979, p. 161).

TABLE 2

Percentage of Population Receiving Poor Relief in 13 Largest Distressed Poor Law Unions, September 1861-November 1862

\begin{tabular}{|c|c|c|c|c|c|c|c|}
\hline \multirow{2}{*}{ Poor law union } & \multirow{2}{*}{$\begin{array}{l}\text { Adults } \\
\text { employed } \\
\text { in cotton/ } \\
\text { population }\end{array}$} & \multicolumn{5}{|c|}{ Percentage of population receiving poor relief } & \multirow{2}{*}{$\begin{array}{l}\text { \% Change in } \\
\text { number on } \\
\text { relief Sept. } \\
\text { 1861-June } 1862\end{array}$} \\
\hline & & $\begin{array}{c}\text { September } \\
1861\end{array}$ & $\begin{array}{c}\text { February } \\
1862\end{array}$ & $\begin{array}{l}\text { June } \\
1862\end{array}$ & $\begin{array}{c}\text { September } \\
1862\end{array}$ & $\begin{array}{c}\text { November } \\
1862\end{array}$ & \\
\hline Ashton-under-Lyne & 20.7 & 1.3 & 3.4 & 7.1 & 15.2 & 25.6 & 443.6 \\
\hline Blackburn & 21.7 & 2.3 & 7.7 & 9.6 & 14.7 & 20.0 & 313.3 \\
\hline Bolton & 14.2 & 2.4 & 3.3 & 3.4 & 4.2 & 6.7 & 44.3 \\
\hline Burnley & 18.2 & 1.8 & 3.3 & 4.5 & 8.8 & 11.2 & 143.3 \\
\hline Bury & 16.9 & 1.9 & 3.7 & 3.8 & 7.6 & 11.7 & 98.4 \\
\hline Chorlton & 4.7 & 1.5 & 2.2 & 2.7 & 4.4 & 9.0 & 74.2 \\
\hline Manchester & 11.5 & 3.4 & 6.4 & 7.7 & 11.7 & 21.1 & 125.7 \\
\hline Oldham & 16.3 & 1.6 & 2.6 & 2.8 & 6.5 & 14.2 & 73.3 \\
\hline Preston & 17.5 & 2.9 & 10.5 & 11.0 & 15.3 & 21.0 & 275.7 \\
\hline Rochdale & 12.9 & 2.2 & 4.5 & 4.8 & 9.8 & 15.2 & 120.2 \\
\hline Salford & 7.3 & 2.5 & 4.1 & 4.4 & 6.4 & 10.9 & 79.4 \\
\hline Stockport & 18.8 & 1.6 & 4.8 & 6.4 & 10.2 & 13.0 & 306.1 \\
\hline Wigan & 6.3 & 2.8 & 3.2 & 3.8 & 4.6 & 5.8 & 37.7 \\
\hline
\end{tabular}

Sources. Data on the number of relief recipients are from Great Britain, Parliamentary Papers (1862, XLIX, Pt. 1, pp. 122-177; 1863, LII, pp. 182-192).

Figure 2 presents a comparison of the trends in the share of the population on relief for three sets of poor law unions: the six unions used by Kiesling; Ashton-under-Lyne, Blackburn, and Preston (ABP), the three unions most affected by the famine; and Bolton and Wigan (BW), two unions largely unaffected by the famine before the fall of 1862. In August and September 1861 the share receiving relief was roughly similar for the three series, but their trends began to diverge soon thereafter. In ABP, the share on relief increased to 7.0\% in February 1862, to 9.1\% in June, and to $15 \%$ in September. The share on relief grew at a much slower rate in Kiesling's six unions, reaching 4.5\% in February 1862, 5.5\%) in June, and 9.4\% in September. The differences in trends between the ABP and the BW series are striking. In Bolton and Wigan the share on relief increased from 2.6\% in September 1861 to 3.6\% in June 1862 and 4.3\% in September. In September 1861 the share of the population receiving relief was slightly higher in BW than in ABP; by September 1862 the share on relief was more than three times larger in ABP than in BW.

Kiesling's conclusion that the poor law was an institution of last resort is based on her finding that, in the six poor law unions she analyzes, numbers on relief did not begin to increase rapidly until the fall of 1862, while the cotton famine began in the fall of 1861 . However, her data do not offer a proper measure of the role of poor relief during the early months of the famine, because only two of her six unions, Ashton-under-Lyne and Preston, were strongly affected by the shortage of American cotton during the winter of 1861-1862, and two other unions, Bolton and Wigan, were among those least affected by the famine. In Ashton, Blackburn, Preston, and

population of the poor law union in 1861. While they understate the share of the adult population employed in cotton manufacturing, the percentages reported enable one to compare the importance of the cotton industry across poor law unions. 
Stockport, the four unions most affected by the shortage of American cotton during the early months of the famine, the number of relief recipients more than tripled from September 1861 to February 1862 and more than quadrupled from September 1861 to June 1862. The number of able-bodied relief recipients in these four unions rose from 4321 in the first week of July 1861 to 32,233 in the first week of July 1862, an increase of $645 \%{ }^{9}$. This rapid increase in numbers on relief is evidence of the important role played by the poor law in these unions in the winter and spring of 1862.

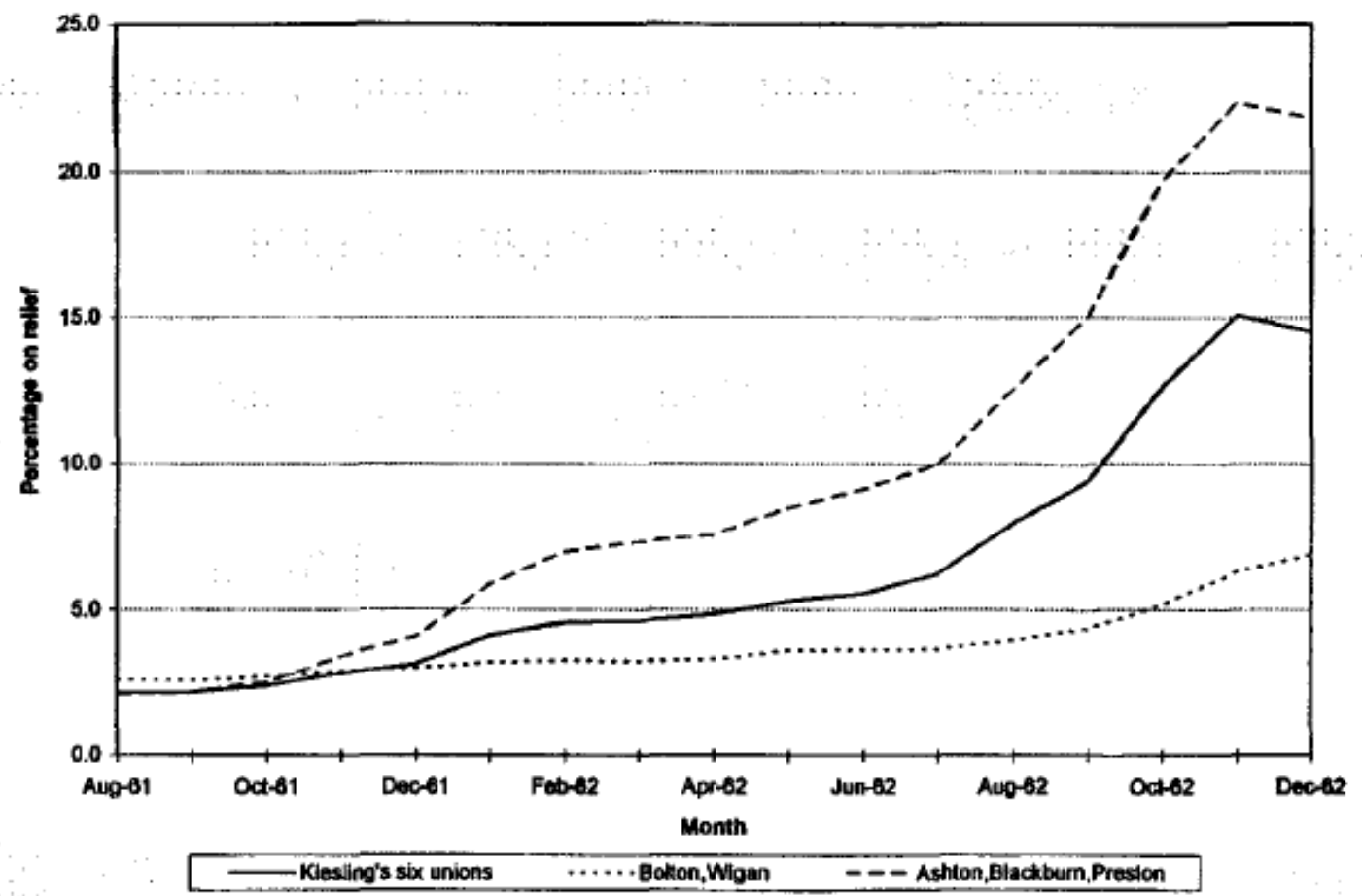

Fig. 2. Percentage of population receiving poor relief, August 1861-December 1862.

The fact that the number of able-bodied and non-able-bodied relief recipients peaked at the same time does indeed suggest, as Kiesling argues, that many non-able-bodied persons were assisted by informal methods during the early part of the cotton famine. However, one should be careful in interpreting this result. For one thing, we do not know what share of non-able-bodied working-class individuals were in receipt of poor relief either before or during the cotton famine. The number of non-able-bodied relief recipients roughly doubled between January 1861 and January 1863. It is conceivable that one-third or more of non-ablebodied working-class individuals received poor relief in January 1861, which would indicate both that many non-ablebodied individuals were assisted by informal methods and that the poor law was an important source of income for the non-able-bodied before the cotton famine. Such a conclusion is supported by the work of Thomson (1986, p. 370), who contends that during much of the nineteenth century working-class individuals "could look with a near-certain expectation of regular and prolonged assistance in old age" from the poor law.

\footnotetext{
9 For the same period, the number of able-bodied relief recipients in Bolton and Wigan increased by 75\%. From the first week of July 1861 to the first week of January 1862, the number of able-bodied relief recipients increased by $166 \%$ in the four unions most affected by the shortage of American cotton and by 30\% in Bolton and Wigan. Data on the number of able-bodied relief recipients are from Great Britain, Parliamentary Papers (1861, LIU, pp. 167, 169,229,231; 1862, XLVIII, pp. 167, 169). It will be recalled that these data are available for only 2 weeks a year-the first week in January and the first week in July
} 
The fact that many cotton operatives supported their aged relatives is not evidence that, when unemployed, they viewed the poor law as an institution of last resort. Coresident aged relatives performed services, such as child-minding and housekeeping, and they often enabled young mothers to work in the cotton factories. In this way, "parents who were supported . . . [made] reciprocal contribution[s] to the family's finances" (Anderson, 1971, pp. 141-144).

Finally, not all of the able-bodied cotton operatives who supported their infirm relatives did so by choice. The poor law made "explicit the expectation that individuals would support close relatives, and it was important in extreme cases in enforcing the obligation" (Dupree, 1995, pp. 309-310). Boards of Guardians might have put pressure on cotton operatives to support their aged parents. Of course, when unemployed operatives applied for poor relief, the aged relatives they were assisting also would be forced to apply for relief.

\section{Section II.}

Kiesling (1996, p. 69) maintains that cotton operatives were paid "some of the highest wages in the industrial occupations," which enabled them "to save and accumulate assets." She does not, however, present any evidence regarding the size of the average operative's savings in 1861. In this section I examine the role of individual saving as a method of income assistance during downturns and offer evidence suggesting that the average cotton worker's savings could not have been large enough to enable him when unemployed to subsist for more than 6-8 weeks.

Wood (1910) reports extensive wage data for cotton operatives during this period. In 1859-1861, just before the cotton famine began, the average wage of spinners was $24 \mathrm{~s} .4 \mathrm{~d}$. per week, while that of power loom weavers was $12 \mathrm{~s} .6 \mathrm{~d}$. per week ${ }^{10}$. Women and children were employed as winders, reelers, piecers, and helpers and were paid 5-10s. per week (Wood, 1910, pp. 28-29,42). The average weekly wage for all cotton factory operatives in 1860 was lls.7d.(Wood, 1910, p. 128) ${ }^{11}$. However, 1860 was a boom year and wages were exceptionally high. During the decade 1851-1860 the average wage was 10.3s. per week. By comparison, during the decade preceding the 1847-1848 downtown the average wage was 9.5s. per week (Wood, 1910, pp. 127-128). The average real wage of cotton factory workers increased by $11.0 \%$ from 1837-1846 to $1851-1860^{12}$. This suggests that the savings of the average cotton worker in 1861 was only slightly larger than that of the average cotton worker in 1847 and therefore that the lag between becoming unemployed and applying for poor relief should have been similar for the two downturns.

The ability to save varied greatly across cotton operatives' households, being determined by the household head's wage, family size, and the number of household members working. A household consisting of a class 1 spinner (earning 39.5s. per week in 1859-1861), a wife employed as a winder or reeler, and two teenage boys employed as piecers would have had a weekly income of about $£ 3$ in 1860 . But the number of class 1 spinners was relatively small, and few households could have had weekly incomes as high as £3. A household consisting of a class 3 spinner, a wife employed as a winder, and no employed children would have had a weekly income of about 30s. Finally, a household consisting of a power-loom weaver, an employed wife, and one employed child would have had a weekly income of perhaps 27s.; if the wife did not work, weekly income would have been less than $£ 1$.

Anderson (1971, p. 128) estimated that the cost of subsistence for a husband and wife in mid-nineteenth century Lancashire was 9s.8d.10s.2d. per week and that the additional cost of a child was 2 s.10d. Thus, the cost of subsistence for a family with two children was 15s. 10d.; for a

\footnotetext{
10

Class 1 spinners earned 39s.6d. per week, class 2 spinners earned 22s.6d., and class 3 spinners earned 2 ls.6d. on average (Wood, 1910, p. 28). The fact that the average wage for all spinners was 24s.4d. indicates that the percentage of class 1 spinners was small. 11 12

The wage reported is the average for men, women, and children combined. Wood does not report the average wage for adult males.

Cost of living estimates for 1837-1846 and 1851-1860 are from Williamson (1985, pp. 216, 220).
} 
family with four children it was 21s.6d. Other studies suggest that Anderson's estimates of the cost of subsistence are somewhat low. Barnsby's (1971, pp. 228-229) detailed analysis of workers' expenditures in the Black Country indicated that the "minimum necessary expenditure" for a family with two small children was 15s.6d.-18s. per week in 1850 and perhaps 2s. higher in 1860, while Dupree (1995, p. 358) estimated that in the Potteries in 1861 the cost of subsistence for a family with two children was $17 \mathrm{~s} .2 \mathrm{~d}$. per week ${ }^{13}$.

During prosperous times the consumption of most well-paid cotton operatives was well above the subsistence level. Arnold (1865, pp. 75-76) wrote that cotton operatives were "accustomed to live well." He went on to say that

while they are not wasteful, they are not saving. Of food they have the best, which they consume in quantities far larger than the requirements of healthy life demand. Teetotalism is not common among them, and not a few are large consumers of ardent spirits. (Arnold, 1865, p. 106)

Similarly, Drs. George Buchanan and Edward Smith, who studied the health of cotton workers during the famine, observed that they "spent liberally on food" during normal times (Oddy, 1983, p. 77). Buchanan noted that well-paid operatives did not see "the advantages of a careful domestic economy, and now in hard times they have no knowledge how to make the most of their scanty incomes" (quoted in Henderson, 1934, p. 101).

A household with a weekly income of $£ 3$, even if it was "accustomed to live well," would have been able to save a few shillings a week. On the other hand, the ability to save of a household with a weekly income of 30s. or less depended on family size and consumption patterns. Anderson (1971, p. 32) concluded that "few even in good times could afford to save anything very significant to meet temporary losses in income ... so that even short or comparatively minor crises caused severe destitution." As evidence of working-class savings, Kiesling cites Watts's (1866, p. 339) estimate that in 1861-1864 there was an excess of withdrawals over deposits of $£ 550,000$ from savings banks in the cotton districts. Watts maintained, however, that

only a small portion of the deposits in those institutions belongs to the operatives, properly so called; the bulk represents in a much larger degree the savings of domestic servants, of the children of small tradesmen, and of the lower stratum of the middle class generally. (Watts, 1866, p. 338)

No evidence exists on the extent of cotton households' savings in 1860, but we can get a rough idea of its magnitude by examining evidence on working-class savings circa 1900 collected by Johnson (1985). In 1899, 83\% of accounts in Post Office Savings Banks had a balance of under $£ 25$; the average balance in these accounts was $£ 4$, and the median balance was even smaller. The average balance of accounts under $£ 50$ was $£ 6$ in 1894 . As late as $1929,72 \%$ of accounts had balances of less than $£ 20$, with an average balance of $£ 3.4$ (Johnson, 1985, pp. 100102). Johnson (1985, p. 103) considered $£ 50$ to be "an upper limit for most working-class savings bank deposits" in 1911-1913. Even if all balances below $£ 50$ in 1894 or 1899 were held by working-class households, which is unlikely, the median working-class balance could not have been greater than $£ 5$. Real wages for manual workers were 85\% higher in 1901 than in 1861 (Feinstein, 1995, p. 31). The median savings account balance held by cotton operatives in 1860

\footnotetext{
13 Bamsby (1971, pp. 228-229) estimated that the "minimum necessary expenditure per week" for a family of four in 1850 was 25s.2'/4d., but he includes expenditures on services, savings, newspapers, etc. The cost of food, housing, fuel, household necessities, shoes and clothing, and household durables totaled 15s.63/4d. per week. Barnsby described the food allotment in his budget as "very spartan." Adding expenditures on drink and tobacco brings the total to $18 \mathrm{~s} .21 / 2 \mathrm{~d}$.
} 
therefore was almost certainly less than $£ 3$, and a significant share of operatives must have had no money at all in savings banks.

Given the cost of subsistence noted above, an unemployed cotton worker with a wife and two small children could subsist for about 4 weeks on $£ 3$ savings, while a cotton worker with four children could subsist for about 3 weeks on $£ 3^{14}$. If unemployed workers and their families moved in with kin in order to save money on rent and fuel, they could subsist for a few more weeks on their savings ${ }^{15}$. On the other hand, cotton operatives who spent several weeks on short time used up some of their savings before being laid off and therefore when unemployed were able to subsist for fewer weeks (Boot, 1990, p. 226).

Kiesling and others maintain that, once their savings were exhausted, many unemployed operatives pawned furniture, clothing, bedding, and other items in order to avoid applying for relief ${ }^{16}$. I have not been able to find any estimates of how much money the typical cotton operative in 1862 could have obtained from pawning such items. Johnson (1985, p. 167) concludes that "most goods pawned ... were of low value." It seems unlikely that a family of four or larger could have subsisted for more than a few weeks on the money obtained from pawning their goods. Moreover, it is not clear what share of unemployed operatives resorted to pawning before applying for poor relief.

By draining their savings accounts, pawning household items, and moving in with kin, unemployed cotton operatives were able to subsist for several weeks without public assistance. The length of time that a household could subsist depended on the amount of its savings, a function of income and consumption patterns, and its subsistence costs, a function of family size. From the evidence presented here, I would estimate that a typical unemployed operative could subsist for $4-8$ weeks. Some highly paid spinners with relatively large savings account balances could have subsisted for much longer, while lower-paid operatives with no money in savings accounts and large families could have subsisted for only a few weeks. On the whole, the evidence on the role of individual saving is consistent with the estimates of the lag between becoming unemployed and applying for relief presented in Section I.

\section{Section III.}

What role did the poor law play in the relief of unemployed cotton operatives? Kiesling contends that unemployed operatives lived off their savings for as long as possible, then pawned household items and moved in with kin. When these informal sources of income became inadequate, they turned to private charity. Unemployed workers did not apply for poor relief until they had exhausted all other alternatives, and the availability of private charity kept some operatives "off of public relief entirely" (Kiesling, 1996, p. 76). Workers turned first to informal assistance because they were "horrified at the thought of being branded a pauper by accepting public relief; they applied for poor relief "only once private charity diminished" because they attached less stigma to receiving charity than poor relief (Kiesling, 1996, pp. 71, 79).

The statement that workers were afraid of "being branded a pauper" implies that unemployed operatives who applied for poor relief during downturns were classified as ordinary paupers. This typically was not the case. Public opinion considered downturns in trade "to be outside the control of the workmen" (Dupree, 1995, p. 321). Partly in response to this view,

\footnotetext{
14 The cost of subsistence was higher for a worker supporting one or two aged parents, and therefore the length of time he and his family could subsist on a given level of savings was smaller.

15 Anderson (1971, p. 201) estimates that the minimum weekly expenditure on food for a family of four was 10s.6d. in 1851. Thus an unemployed worker with a wife and two children who moved in with kin and spent money only on food could subsist for about 6 weeks on $£ 3$ savings.

16 See Kiesling (1996, p. 72), Henderson (1934, p. 98), and Anderson (1971, p. 150). For a discussion of the importance of pawn broking for working-class households in Victorian Britain, see Johnson (1985, pp. 165-188).
} 
Boards of Guardians differentiated between cyclically unemployed operatives and "confirmed paupers"; they argued that "it was degrading for those unemployed through no fault of their own to be set to work with idle and dissolute paupers" (Rose, 1970, p. 133; Edsall, 1971, pp. 248-249). The contention that operatives attached less stigma to receiving private charity than to poor relief, while accepted by some contemporaries and historians, is rejected by others. According to Arnold (1865, p. 99), "as a rule, the operatives greatly preferred to be pensioners of the [charity] committees rather than of the guardians." However, MacKay, who strongly supported the use of voluntary action to meet "extraordinary crises," concluded that

the arguments, therefore, that the labourer preferred charity to the Poor Law . . . is largely contrary to fact.. . if there is a preference, it is rather the other way, namely, for a subvention from the rates to which he himself contributes, and to which... he may be persuaded that he has a right. (MacKay, 1899, p. 419)

Kiesling's contention that the sources of income for unemployed operatives passed through distinct stages, from informal assistance to private charity to poor relief, is not supported by the available evidence. Large numbers of unemployed workers received poor relief and private charity at the same time. The Manchester and Salford District Provident Society "made it their rule to assist only those who Were accepted as proper recipients by the Poor Law," and the majority of persons receiving poor relief in Preston and Oldham in the fell of 1862 also received assistance from local charity (MacKay, 1899, p. 413; Arnold, 1865, pp. 136, 144-145) ${ }^{17}$. MacKay (1899, p. 413) concluded that "over a considerable part of the [distressed area] . . charitable funds were used to supplement the Poor Law Allowance.

There is no evidence that the majority of unemployed workers turned to poor relief "only once private charity diminished." The number of poor relief recipients began to increase rapidly in July 1862 and peaked in December $1862^{18}$. According to Kiesling (1996, p. 76), "private charity increased dramatically during 1862, then fell off over the course of 1863." Thus, the increase in poor relief recipients was not preceded by a sharp decline in private charity. Henderson (1934, p. 68) suggests that the increase in private charity was largely a response to the inadequacy of poor relief: "the Poor Law was unable to stand the exceptional strain put upon it by the Cotton Famine.... The help which the operatives so urgently needed, had, therefore, to come from private charity."

Poor law guardians and charity officials agreed that the minimum amount of income necessary to maintain unemployed workers and their families in good health was about 2s. per person per week (Watts, 1866, pp. 199-200; Henderson, 1934, pp. 99-100; Rose, 1977, p. 191). Data reported by Kiesling (1996, p. 83) indicate that during the height of the cotton famine poor relief expenditures averaged less than ls.6d. per person per week. Local Boards of Guardians realized that the relief they were granting was inadequate and "assumed that this meagre sum would be augmented from other sources, short-time earnings, income from other members of the femily or charitable aid" (Rose, 1977, p. 189) ${ }^{19}$. Their assumption appears to have been correct. According to Arnold (1865, p. 191), "a large number" of the 248,000 persons receiving outdoor relief in the last week of December 1862 "were receiving supplementary aid from the relief committees." Many of those receiving poor relief must also have been getting informal assistance from family members or neighbors. Dupree (1995, p. 315) concluded from her analysis of the role of family assistance in the Potteries during this period that poor relief was not "a mutually

\footnotetext{
17 On the other hand, in Rochdale and Stockport private charity was only offered to persons "who received no help from the guardians" (Arnold, 1865, pp. 145-146).

18 See above, Fig. 1 and Table 2.

19

The chairman of the Ashton Board of Guardians commented in the spring of 1863 that "surely no one expected that what the guardians gave was enough of itself" (quoted in Rose, 1977, p. 189).
} 
exclusive alternative to family relationships as a source of assistance. Instead, resort to assistance from family members and from out-relief were closely related and they could exist simultaneously."

Weekly poor relief payments to unemployed operatives and their families were somewhat smaller during the cotton famine than during previous downturns, when grants averaged between ls.6d. and 2s. per person per week (Rose, 1965, pp. 195-196). The administrators of charitable funds, anxious that their funds should "relieve the destitute and not the ratepayers," argued that poor relief expenditures should be raised to 2s. per head per week. The Guardians replied that such an increase would require an "oppressive increase in the rates" (Arnold, 1865, pp. 150-152). The poor rates were assessed largely on property that depended on the cotton trade, so that the same factors that increased the demand for poor relief also reduced the effective tax base of the distressed areas. Relief payments therefore were relatively small during the famine because Boards of Guardians either would not or could not raise taxes by enough to maintain the exceptionally large number of applicants at the usual level of generosity ${ }^{20}$.

Most contemporaries agreed that the demand for poor relief during the cotton famine was unprecedented. Arnold (1865, p. 208) wrote that "the incidence of the poor-rate was never so oppressive over an equal extent of the kingdom as in the cotton districts during the months which included the crisis of the famine," and MacKay (1899, p. 388) concluded that the cotton famine was "the most serious crisis with which the English Poor Law has ever been called on to grapple." The poor law was unable to meet this unprecedented demand, and so private charity played a larger role during the famine than it did in any previous downturn. As a result, an analysis of the sources of income assistance to unemployed operatives that focuses on the cotton famine will significantly overestimate the importance of private charity, and underestimate the importance of poor relief, during the period $1830-1870^{21}$.

\section{Section IV.}

In my earlier work on the role of poor relief in industrial cities, I stated that in many cities workers on short time were eligible for poor relief, and that as a result employers initially responded to downturns by reducing hours per worker, and only began to lay off workers when the state of the economy became "sufficiently bad" (Boyer, 1990, pp. 240-241). In fact, for many employers the use of worksharing was part of a cost-minimizing strategy even if workers on short time were not eligible for relief. Risk averse workers preferred worksharing to random layoffs. So long as employers were not made worse off by worksharing, they should have agreed to reduce hours during minor downturns. However, most firms faced a minimum hours constraint, so that when economic conditions got sufficiently bad employers resorted to layoffs ${ }^{22}$.

This theory appears to accurately depict the response of employers in the textileproducing districts to fluctuations in demand. Kiesling (1996, p. 70) and Arnold (1865, pp. 57-58, 68-69) provide evidence that short time preceded layoffs during the cotton famine. Similarly, Boot (1990, pp. 220-221) found that short time preceded layoffs in Manchester during the 18471848 depression, and Huberman (1986, p. 992; 1987, pp. 189-190) maintained that, in the 1830s and 1840s, urban Lancashire cotton firms worked short time during minor downturns, and turned to layoffs during prolonged slumps.

While short time was an important part of implicit labor contracts throughout the period, during the cotton famine the relationship between worksharing and poor relief was significantly

\footnotetext{
20

20 This conclusion is supported by the work of Stephen Easton (1978, pp. 327-329), who found a significant negative relationship between the number of outdoor relief recipients and the generosity of relief benefits in England and Wales from 1857 to 1910.

21 The Crusade against Outrelief led to a radical change in English poor law policy after 1870. See MacKinnon (1987).

22 For an analysis of the role of worksharing in implicit contracts models, see Rosen (1985, pp. 1162-1165) and Burdett and Wright (1989).
} 
different than in earlier decades. Kiesling (1996, pp. 73, 70) states that workers on short time "could not receive public relief to supplement their wages," and therefore worksharing "obviated worker movement to public relief." In contrast, during the 1830s and 1840s factory workers on short time received poor relief in many Lancashire and West Riding cities. For example, the clerk of the Bolton Poor Law Union testified in 1841 that "in consequence of the working of the factories half time, the applications from all classes of operatives... for relief on the ground of insufficiency of earnings, have been numerous and pressing during the last two years." The Bolton Guardians granted applicants enough relief to make up their income "to 2s.3d. per head per week for the whole of the family, where we clearly ascertain the amount [the applicant's family] earned" (Parliamentary Papers, 1846, XXXVI, pp. 12-13).

According to Rose (1965, p. 199), before 1834 "most poor relief authorities [in the industrial Northwest] felt quite justified in making small payments to factory workers whose hours or wages had been reduced during a period of depression." Boards of Guardians in Lancashire and the West Riding continued "this established practice" under the new poor law ${ }^{23}$. It is not possible to determine the extent to which factory workers on short time received poor relief during the 1840s. One piece of evidence suggesting that the practice was widespread is the "storm of protest" from Boards of Guardians in the industrial Northwest in response to the Outdoor Relief Regulation Order of August 1852, which, among other things, forbade the payment of poor relief to able-bodied males in employment. The protests caused the Poor Law Board to modify the Order in such a way as to make evasion easy (Rose, 1970, pp. 134-135) ${ }^{24}$.

The evidence presented here indicates that during the 1830s and 1840s worksharing was not necessarily a substitute for poor relief, as Kiesling contends. Of course, not all factory workers on short time applied for or received poor relief. Highly paid operatives probably were able to subsist on their wages even if the work week was cut from 6 to 4 days, but many lowerpaid operatives could not have subsisted on two-thirds or, if they had several small children, even five-sixths of their usual weekly income. Boot (1990, p. 226) maintains that the reduction in earnings associated with short-time work caused many factory operatives "to sell off assets, use up savings, or go into debt." Many others turned to the poor law for assistance.

Unlike in earlier downturns, during the cotton famine few workers on short time received poor relief. Most operatives working 3 or 4 day weeks therefore would have been forced to deplete their resources or move in with kin in order to subsist, so that when they eventually became unemployed the length of time they could have gone without applying for poor relief and/or private charity was quite short. Kiesling's contention that operatives spent extended periods working short time and then, when unemployed, subsisted for several months on informal sources of income is plausible only for a very small number of highly paid spinners with large savings account balances.

Finally, it is important to note that workers' preference for worksharing over random layoffs does not imply that they attached a stigma to receiving poor relief. A cotton spinner working a 4 or 5 day week typically had an income significantly higher than the payment he would have received from the guardians if unemployed ${ }^{25}$. Moreover, worksharing offered employment stability; a worker who was laid off had no guarantee that he would be rehired by the same firm when the economy recovered. Thus, even if workers attached no stigma to receiving poor relief, they would have preferred worksharing to random layoffs.

\footnotetext{
23 For evidence of the payment of poor relief to factory workers on short time after 1834, see Rose (1966, pp. 614-616).

24

24 The amended order prohibited "the giving of relief at the same identical time as that at which the person receiving it is in actual employment, and in the receipt of wages." It did not prohibit granting relief to "a man working for wages one day and being without work the next, or working half the week and being unemployed during the remainder" (Arnold, 1865, pp. 49-50).

25

25 Relief payments to unemployed workers were based on family size. (See Section III.) An unemployed operative with a wife and two (four) children typically would have received 7-8s. (10-1 Is.) per week from the guardians. For comparison, in 1859-1861 a class 3 spinner working a 4 (5)-day week would have earned 14s.5d. (17s.lld); a class 1 spinner would have earned 26s.5d. working a 4-day week.
} 


\section{Section V.}

My earlier work overstated the similarities between poor relief in early Victorian cities and current unemployment insurance systems. However, Kiesling's conclusion that "the poor law provided an insurance institution of final recourse" significantly understates the importance of poor relief. The evidence presented here indicates that the poor law was a major source of income assistance to unemployed cotton operatives during the Lancashire cotton famine and that it played an even larger role in assisting unemployed and underemployed workers during the downturns of the 1830s and 1840s.

Kiesling's main piece of evidence in support of the conclusion that workers viewed poor relief as a last resort is her finding that the lag between the beginning of the cotton famine and the widespread application for poor relief was as long as 14 months. However, her calculation is based on semiannual data on the number of relief recipients, and it does not take into account the fact that the cotton famine got much worse over time-raw cotton consumption collapsed in the late summer of 1862, not the fall of 1861. My comparison of weekly data on the number of relief recipients with estimates of weekly cotton consumption for the period November 1861 to December 1862 suggests that the average length of time between becoming unemployed and applying for poor relief was about 4-8 weeks. This is similar to Boot's finding of a 6-week lag for Manchester cotton workers during the 1847-1848 downturn. It also is consistent with the evidence on working-class savings presented in Section II.

Unemployed cotton workers faced a variety of "assistance alternatives" during the Lancashire cotton famine. Kiesling stresses the role played by informal assistance and private charity and maintains that unemployed operatives applied for poor relief only after they had exhausted all other sources of income assistance. The evidence presented here does not support her scenario. Most cotton workers had very little savings and could not have subsisted for more than 6-8 weeks on "informal assistance" even if they had pawned household items and moved in with kin. Moreover, while private charity played a larger role during the cotton famine than in any previous downturn, there is no evidence that a large share of unemployed operatives applied for poor relief "only once private charity diminished." In fact, unemployed workers in many Lancashire cities received poor relief and private charity at the same time.

Whether or not operatives were averse to receiving poor relief, given the meager amount of informal assistance available to them, most were forced to turn to the poor law for assistance during downturns in trade. It was for this reason that for three decades after 1834 both workers and local relief administrators in Lancashire fought against, and succeeded in blocking, all attempts to end the granting of outdoor relief to unemployed workers. 


\section{APPENDIX}

Weekly Raw Cotton Consumption, September 1861-December 1862

\begin{tabular}{lccc}
\hline Week-Month-Year & $\begin{array}{c}\text { Raw cotton consumption } \\
\text { (in bales) }\end{array}$ & Week-Month-Year & $\begin{array}{c}\text { Raw cotton consumption } \\
\text { (in bales) }\end{array}$ \\
\hline 1-Sept 1861 & 37,320 & 5-Apr & 26,260 \\
2-Sept & 56,810 & 1-May & 19,570 \\
3-Sept & 56,810 & 2-May & 17,220 \\
4-Sept & 30,110 & 3-May & 20,200 \\
1-Oct & 40,280 & 4-May & 31,620 \\
2-Oct & 49,330 & 1-Jun & 45,970 \\
3-Oct & 32,000 & 2-Jun & 36,720 \\
4-Oct & 32,000 & 3-Jun & 47,660 \\
1-Nov & 32,000 & 4-Jun & 53,240 \\
2-Nov & 42,490 & 1-Jul & 23,880 \\
3-Nov & 16,650 & 2-Jul & 17,270 \\
4-Nov & 13,040 & 3-Jul & 10,420 \\
1-Dec & 15,640 & 4-Jul & 9,795 \\
2-Dec & 22,620 & 5-Jul & 9,795 \\
3-Dec & 15,030 & 1-Aug & 18,490 \\
4-Dec & 14,890 & 2-Aug & 21,580 \\
5-Dec & 28,790 & 3-Aug & 40,700 \\
1-Jan 1862 & 28,790 & 4-Aug & 14,410 \\
2-Jan & 17,250 & 1-Sept & 7,570 \\
3-Jan & 10,530 & 2-Sept & 6,480 \\
4-Jan & 24,370 & 3-Sept & 9,440 \\
1-Feb & 18,900 & 4-Sept & 6,230 \\
2-Feb & 26,940 & 1-Oct & 5,900 \\
3-Feb & 49,350 & 2-Oct & 9,170 \\
4-Feb & 30,570 & 3-Oct & 4,210 \\
1-Mar & 22,570 & 4-Oct & 11,800 \\
2-Mar & 21,520 & 5-Oct & 14,930 \\
3-Mar & 24,140 & 1-Nov & 14,930 \\
4-Mar & 17,440 & 2-Nov & 10,740 \\
1-Apr & 19,290 & 3-Nov & 10,700 \\
2-Apr & 42,080 & 1-Dov & 21,930 \\
3-Apr & 39,120 & & 31,520 \\
4-Apr & 34,160 & \\
\hline
\end{tabular}

Source. Calculated from weekly estimates of year-to-date raw cotton consumption reported in The Economist, weekly issues, September 1861 to December 1862. 


\section{References}

Anderson, Michael (1971), Family Structure in Nineteenth Century Lancashire. Cambridge, UK: Cambridge Univ. Press.

Arnold, R. Arthur (1865), The History of the Cotton Famine. London: Saunders, Otley, and Co.

Bamsby, George J. (1971), "The Standard of Living in the Black Country during the Nineteenth Century." Economic History Review, 2nd Series 24,220-239.

Boot, H. M. (1990), "Unemployment and Poor Law Relief in Manchester, 1845-50." Social History 15,217-228.

Boyer, George R. (1990), An Economic History of the English Poor Law I750-1850. Cambridge, UK: Cambridge Univ. Press.

Burdett, Kenneth, and Wright, Randall (1989), "Unemployment Insurance and Short-Time Compensation: The Effect on Layoffs, Hours per Worker, and Wages." Journal of Political Economy 97, 1479-1496.

Clapham, J. H. (1932), An Economic History of Modern Britain, Vol. 2. Cambridge, UK: Cambridge Univ. Press.

Dupree, Marguerite W (1995), Family Structure in the Staffordshire Potteries 1840-1880. Oxford: Clarendon.

Easton, Stephen (1978), "The British Outdoor Relief System: 1857-1910." In Herbert Grubel and Michael Walker (Eds.), Unemployment Insurance: Global Evidence of Its Effects on Unemployment. Vancouver: Fraser Institute. Pp. 320-337. The Economist (1861-1863), various issues.

Edsall, Nicholas C. (1971), The Anti-Poor Law Movement 1834-1844. Manchester: Manchester Univ. Press.

Farnie, D. A. (1979), The English Cotton Industry and the World Market 1815-1896. Oxford: Clarendon.

Feinstein, Charles (1995), "Changes in Nominal Wages, the Cost of Living and Real Wages in the United Kingdom over Two Centuries, 1780-1990." In P. Scholliers and V. Zamagni (Eds.), Labour's Reward. Aldershot, UK: Edward Elgar. Pp. 3-36.

Great Britain, Parliamentary Papers (1846, XXXVI), A Copy of Reports Received by the PoorLaw Commissioners in 1841, on the Stale of the Macclesfield and Bolton Unions.

Great Britain, Parliamentary Papers (1861, LIII; 1862, XLVIII), Comparative Statement of the Number of Paupers ... in Receipt of Relief.

Great Britain, Parliamentary Papers (1862, XLIX), Return of the Number of Paupers ... in Receipt of Relief in Each Week of the Fourteen Months Ending with December 1858, 1861, and 1862, Respectively. 
Great Britain, Parliamentary Papers (1863, LII), Return ... and Summary of the Number of Paupers Relieved. . . in Each Week of the Twenty-two Months Ending with August 1863.

Henderson, William O. (1934), The Lancashire Cotton Famine 1861-1865. Manchester: Manchester Univ. Press.

Huberman, Michael (1986), "Invisible Handshakes in Lancashire: Cotton Spinning in the First Half of the Nineteenth Century." Journal of Economic History 46, 987-998.

Huberman, Michael (1987), "The Economic Origins of Paternalism: Lancashire Cotton Spinning in the First Half of the Nineteenth Century." Social History 12, 177-192.

Johnson, Paul (1985), Saving and Spending. Oxford: Clarendon.

Kiesling, L. Lynne (1996), "Institutional Choice Matters: The Poor Law and Implicit Labor Contracts in Victorian Lancashire." Explorations in Economic History 33,65-85.

MacKay, Thomas (1899), A History of the English Poor Law, Vol. III. London: P. S. King.

MacKinnon, Mary (1986), "Poor Law Policy, Unemployment, and Pauperism." Explorations in Economic History 23,299-336.

MacKinnon, Mary (1987), "English Poor Law Policy and the Crusade against Outrelief." Journal of Economic History 47, 603-625.

Oddy, D. J. (1983), "Urban Famine in Nineteenth-Century Britain: The Effect of the Lancashire Cotton Famine on Working-Class Diet and Health." Economic History Review, 2nd Series 36, 6886.

Purdy, Frederick (1862), "Extent ofPauperism in the Distressed Unions in Lancashire ... , 186162." Journal of the Royal Statistical Society 25, 377-383.

Rose, Michael E. (1965), The Administration of Poor Relief in the West Riding of Yorkshire c. 1820-1855." D. Phil. Thesis, Oxford University.

Rose, Michael E. (1966), "The Allowance System under the New Poor Law." Economic History Review, 2nd Series 19, 607-620.

Rose, Michael E. (1970), "The New Poor Law in an Industrial Area." In R. M. Hartwell (Ed.), The Industrial Revolution. Oxford: Oxford Univ. Press. Pp. 121-143.

Rose, Michael E. (1977), "Rochdale Man and the Stalybridge Riot: The Relief and Control of the Unemployed during the Lancashire Cotton Famine." In A. P. Donajgrodzki (Ed.), Social Control in Nineteenth Century Britain. London: Croom Helm. Pp. 185-206.

Rosen, Sherwin (1985), "Implicit Contracts: A Survey." Journal of Economic Literature 23, 1144-1175.

Thomson, David (1986), "Welfare and the Historians." In L. Bonfield, R. M. Smith, and K. Wrightson (Eds.), The World We Have Gained. Oxford: Basil Blackwell. Pp. 355-378. 
Watts, John (1866), The Facts of the Cotton Famine. London: Frank Cass. [Reprinted 1968]

Williamson, Jeffrey G. (1985), Did British Capitalism Breed Inequality? Boston: Allen and Unwin. Wood, George H. (1910), The History of Wages in the Cotton Trade during the Past Hundred Years. London: Sherratt and Hughes. 